\title{
Efects of cow urine in the agroecological management of insects and witches' broom (Moniliophtora perniciosa Stahel Aime \&Phillips-Mora) in cacao crops (Theobroma cacao L.)
}

\author{
Efeitos da urina de vaca no manejo agroecológico de insetos e da \\ vassoura-de-bruxa (Moniliophtora perniciosa Stahel Aime \& Phillips- \\ Mora) do cacaueiro (Theobroma cacao L.)
}

\author{
José Eduardo Santos Mamédio' ${ }^{(0)}$, Uberson Boaretto Rossa "(1) , Frederico \\ Fonseca da Silva ${ }^{\prime \prime \prime}\left(\mathbb{D}\right.$, Wilson Sacchi Peternella ${ }^{\mathrm{IV}}$, Vanderlei Bett ${ }^{\mathrm{V}}$ \\ ' Universidade Federal de Santa Maria, Departamento de Química, Santa Maria, RS, Brasil \\ "Instituto Federal Catarinense, Araquari, SC, Brasil \\ II' Instituto Federal do Paraná, Curitiba, PR, Brasil \\ IVUniversidade Federal de Rondônia, Porto Velho, RO, Brasil \\ VInstituto de Desenvolvimento Rural do Paraná, Paranavai, PR, Brasil
}

\section{ABSTRACT}

Witches' broom (Moniliophtora perniciosa Stahel Aime \& Phillips-Mora) was first reported in the state of Bahia (Brazil), in 1989, in areas of cacao cultivation, where it immediately became the most important disease of this culture, responsible for marked losses in production, mainly by weakening the plants and causing leaf area reduction, leading even to the death of the adult plant. After several years of dropping cacao production in the southern region of Bahia, producers have renovated their hopes for farming by adopting practices that favor increments in productivity, such as stand renewal using productive, selfcompatible genetic material that is more resistant to this disease, thus enhancing the cultural management of cacao in agroforestry systems. In order to combat this disease, farmers have resorted to pesticides; however, their indiscriminate use has led to the contamination of workers and the environment, which is increasingly unbalanced and creating resistance to the fungus. Alternative methods to control this disease are already being tested by the producers themselves, who have perceived improvements in their crops and in their quality of life when using them, mainly since they are natural, cheap, and easily accessible, as is the case of cow urine pulverization. In this study, we evaluated the application of cow urine at different concentrations, with five treatments and four repetitions each, using a completely randomized design. The results showed that lactating cow urine at concentrations of $0.5 \%, 1.0 \%$, and $1.5 \%$ was as efficient as the pesticide used as a control in the experiment, simulating 
conventional treatment. However, no significant differences in results were observed when using the Tukey test at $5 \%$ probability.

Keywords: Plant defense, Organic agriculture, Agroforestry system

\section{RESUMO}

A Vassoura-de-bruxa (Moniliophtora perniciosa Stahel Aime \& Phillips-Mora) foi constatada na Bahia pela primeira vez em 1989 nas áreas de cultivo de cacau, e imediatamente tornou-se a mais importante doença dessa cultura, responsável por perdas acentuadas de produção, principalmente pelo enfraquecimento das plantas e a redução da área foliar, causando inclusive a morte da planta adulta. Após vários anos de queda na produção de cacau na região Sul da Bahia, os produtores vêm renovando as esperanças na lavoura ao adotar práticas que favorecem o aumento da produtividade, como renovação do stand por meio de material genético autocompatível e com maior resistência a essa doença, melhorando, assim, o manejo cultural do cacaueiro em sistemas agroflorestais. Dentro de um cultivo convencional, para combater essa doença, os agricultores têm recorrido a pesticidas. Entretanto, o seu uso indiscriminado tem levado à contaminação de trabalhadores e do ambiente, que está cada vez mais em desequilíbrio e criando resistência a esse fungo. Métodos alternativos no controle desta doença, como a pulverização com urina de vaca, já estão sendo testados pelos próprios produtores, que já percebem melhorias nos seus cultivos e na própria qualidade de vida, principalmente por serem produtos alternativos, naturais, baratos e de fácil acesso. Neste estudo, avaliou-se o uso da urina de vaca em diferentes concentrações, utilizando 5 tratamentos com 4 repetições cada, em um delineamento inteiramente casualizado. Os resultados demonstraram que a urina de vaca em lactação, nas concentrações de $0,5 \%, 1,0 \%$ e 1,5\%, foi tão eficiente quanto o pesticida utilizado como referência no experimento, simulando o tratamento convencional, não sendo observadas diferenças significantes em seus resultados de acordo com o teste de Tukey a $5 \%$ de probabilidade.

Palavras-chave: Defesa de plantas, Agricultura orgânica, Sistema agroflorestal

\section{INTRODUCTION}

Originally from the Amazon Basin, cacao (Theobroma cacao L.) was brought to southern Bahia in 1746, where it found excellent climatic and land-based conditions, similar to those encountered in its region of origin (ANDRADE, 2003). For 250 years, Bahian cacao crops prospered, generating wealth and income, occupying 650 thousand hectares in the South of the state and being produced by 29 thousand properties, with one farmer for every 5.0 hectares (PINAZZA and ALIMANDRO, 2001).

The production in Bahia neared 400 thousand tons in the 1980s, dominating 95\% of the national output, and even exported more than US\$ 1 billion in cacao sacks by way of the port of Ilhéus, although it experienced an abrupt drop of $68 \%$ between harvests in 1980/81 and 1999/00. In 2012, Bahian cacao cultivation had 
one of its lowest production volumes, reaching 96 thousand tons (CEPLAC, 2012). The triggering factor for the fall in production, which remains a concern for producers until today, was the contamination of plantations with the fungus Moniliophtora perniciosa Stahel Aime \& Phillips-Mora, responsible for the witches' broom disease. According to IBGE/PAM (2018), the state's production comprised 113,939 tons, indicating the recovery of the production system as a result of the research work in facing the diseases that were plaguing cacao cultures.

As of 1989, witches' broom disease was incorporated into management variables and production costs, and the cacao region of Bahia succumbed to one of the plant diseases with the most destructive effects and with a strong limiting influence on production. The disease affects both vegetative parts and fruits, causing irreversible economic losses (SANTOS FILHO et al., 1998).

The arrival of witches' broom disease in southern Bahia, probably also originating from the Amazon Region (BAKER and CROWDY, 1943), caused a socioeconomic and ecological disaster of unprecedented proportions. The fact, according to Luz et al. (1997), went down in the history of world agriculture as one of the most dramatic examples of the impact of a plant disease on an extensive area of cultivation.

Analyzing the gradient of the disease constitutes one way of studying the spatial growth of an epidemic (BERGAMIN FILHO et al., 2002). Therefore, the shoots and new branches of the plants were evaluated 15 days before and 30 days after cow urine application. The assessment consisted of observing the phytosanitary status of each plant's foliar shoots by counting the number of total foliar shoots and the number of those damaged by insects, according to Evans and Poorter (2001).

The indiscriminate use of pesticides for the control of this disease has led to the contamination of workers (SOARES, 2011) and the agroforestry environment, which is increasingly unbalanced. In addition, the indebtedness of rural producers 
who do not see alternatives to overcome the crisis caused by the disease, which has been plaguing the region for over 20 years, is noteworthy.

The most promising phytosanitary solutions for agroforestry systems, including cacao, are linked to the agroecological management of each crop. Alternative methods of controlling this cacao disease are currently being tested by the producers themselves, who already see improvements in their crops and in the quality of life itself when using them (MAMÉDIO, 2012).

Positive results of cow urine on plant growth, metabolic activation, and pest and disease control have been reported in previous studies (BOEMEKE, 2002; ACHLIYA et al., 2004). In lettuce, the application of $20 \mathrm{~mL}$ per plant of cow urine solution to the soil, at a concentration of $0.86 \%$, provided an increase of $10.3 \%$ in plant fresh matter (GADELHA et al., 2003). In pepper, weekly spraying of urine solutions ( 0 to $5.0 \%$ ) from 15 days after transplant until the second-to-last harvest caused a linear increase in fruit production (OLIVEIRA et al., 2003).

It is considered that cow urine, which is rich in mineral elements, provides nutrients and other beneficial substances to plants at reduced costs. Also, its use does not pose a risk to the health of producers and/or consumers, being practically ready for use, only requiring the addition of water (PESAGRO-RIO, 2002; GADELHA et al., 2003).

In cacao production, there are reports from producers in southern Bahia who tested cow urine to control witches' broom disease. Primary results indicated not only a significant increase in the vegetative development of the plants, but mainly the reduction of up to $95 \%$ in the incidence of the disease in the areas where the product was applied (PESAGRO-RIO, 2012).

Gadelha et al. (2003), when analyzing the chemical composition of cow urine, found several nutrients, including Nitrogen (6,300 ppm), Phosphorus (140 ppm), Potassium (27,100 ppm), Calcium (226 ppm), Magnesium (720 ppm), Sulphur (1.140 ppm), Iron (2.4 ppm), Manganese (0.1 ppm), Boron (44 ppm), Copper (0.2 ppm), Zinc 
(0.1 ppm), Sodium (1,900 ppm), Chlorine (10,600 ppm), Cobalt (1.5 ppm), and Molybdenum (2.0 ppm), as well as traces of other elements.

Consequently, the use of cow urine to control witches' broom disease constitutes another low-cost, easy access, and natural alternative, thus reducing production costs and the risk of intoxication of the agroforester, in addition to not causing an environmental impact.

The aim of the present study was to evaluate the efficiency of using lactating cow urine, in different doses, to control witches' broom disease in cacao cultures in southern Bahia.

\section{METHODS}

This study was conducted on a small rural property located in the community of Cachoeira Alta, in the municipality of Piraí do Norte, in the state of Bahia (Figure 1), where cacao is characterized as being the primary income activity in the region (IBGE, 2019). This location is inserted in an area of cacao crop harvesting, with more than four years of cultivation and uniform shading.

Figure 1 - Location of the municipality of Piraí do Norte on the map of lower southern Bahia

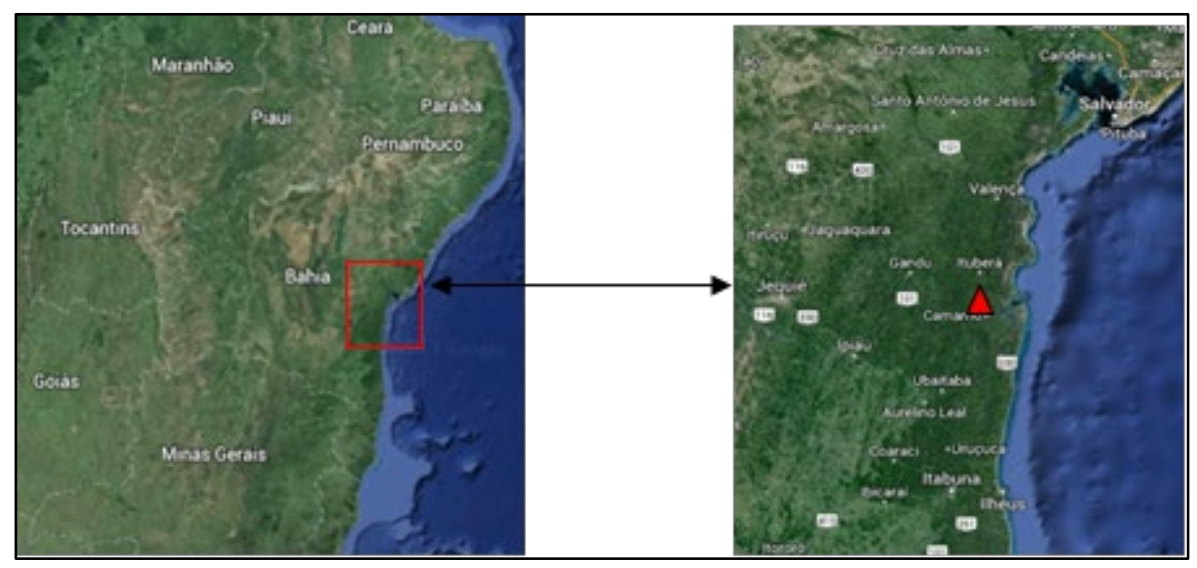

Source: www.google.com.br/maps/preview?hl=pt-BR 
The experiment was performed between February (beginning) and March (end) of 2019, which corresponds to the period with the highest incidence of the disease.

The total area of the experiment comprised $1.0 \mathrm{ha}$, and the study was carried out continuously in order to maintain the same plant stand. Symptoms of the disease were observed throughout the study area during the leaf renewal period and under the same edaphoclimatic conditions.

According to Köppen and Geiger, the climate in the area is classified as Af, characterized as tropical, with temperatures ranging from $25^{\circ} \mathrm{C}$ to $27^{\circ} \mathrm{C}$ (CLIMATE, 2019), luminosity greater than 1,500 hours of light.year-1, and average relative air humidity of $70 \%$. The driest month has an average annual rainfall of $1,610 \mathrm{~mm}$, with excellent distribution throughout the year (FREITAS, 2005).

The study area presents a smooth relief, formed by argisol soils of significant natural fertility, including CEPEC MODAL-type soils - Haplic Nitosol, Eutrophic saprolite, to moderate, hypereutrophic, clayey texture, perennial forest stage and smooth wavy and wavy relief (EMBRAPA SOLOS, 2018).

Regarding the experimental design, five treatments were used (Table 1), with four repetitions each, totaling 20 plots. Each experimental unit consisted of 4 plants per plot, in a completely randomized statistical design.

Table 1- Treatments (products and dosages) applied to control the incidence of Witches' Broom disease in the cacao culture in a producing area in the municipality of Piraí do Norte (BA-Brazil)

T1 - Cow urine $-0.5 \%$ ( $0.5 \mathrm{~L}$ of cow urine in $99.5 \mathrm{~L}$ of water V/V) 1.20

T2 - Cow urine - $1.0 \%$ (1.0 L of cow urine in $99.0 \mathrm{~L}$ of water V/V)

T3 - Cow urine - 1.5\% (1.5 L of cow urine in 98.5 L of water V/V) 
All plants received the conventional cultural treatments used in the region, such as clean pruning, manual mowing, and the application of dolomitic limestone three months prior to the start of the experiment, distributed per plant and equivalent to 2.0 t.ha $^{-1}$.

The vegetation coverage is reminiscent of Atlantic Forest and is still preserved due to the need for natural shading required by the cacao crop.

For Treatments T1, T2, and T3, urine was collected from lactating cows, during the morning milking, in a common pot and, later, stored in a sealed plastic container and kept in a shelter, where it remained for three days before use, following the methodology proposed by Pesagro-Rio (2012).

The dilutions were performed in the proportion (V/V) of each treatment, directly in the motorized backpack sprayer, and application occurred only once a day, in the early hours of the morning.

Based on tests carried out empirically by producers in Rondônia and Bahia, the concentration of $1.0 \%$ (T2) of lactating cow urine was used as the basis. In treatments 1 and 3 (T1 and T3, respectively), concentrations of 0,5\% (corresponding to $50 \%$ of the concentration of T2) and $1.5 \%$ ( $150 \%$ of the concentration of T2) were used.

In the Conventional Treatment (T4), the insecticide Decis ${ }^{\circledR}$ 25EC, whose active ingredient is deltamethrin (pyrethroid class), was used at a dosage of 0.25 L.ha-1, even though the product is not registered by the Ministry of Agriculture, Livestock, and Supply (MAPA) for the control of witches' broom disease. Regarding the field research, we found that conventional farmers use this product, most likely because it is the most used to combat cacao pests. Treatment T5 was used as a control and did not receive any dose, neither pesticide nor lactating cow urine.

Plant spraying was carried out at ambient temperatures below $32^{\circ} \mathrm{C}$, minimum relative air humidity of $55 \%$, and wind speed of $2.0 \mathrm{~km} . \mathrm{h}-1$ up to a maximum of $10 \mathrm{~km} \cdot \mathrm{h}^{-1}$, as shown in Figure 2 . 
Figure 2 - Insecticide application by motorized sprayer and operator using IPE

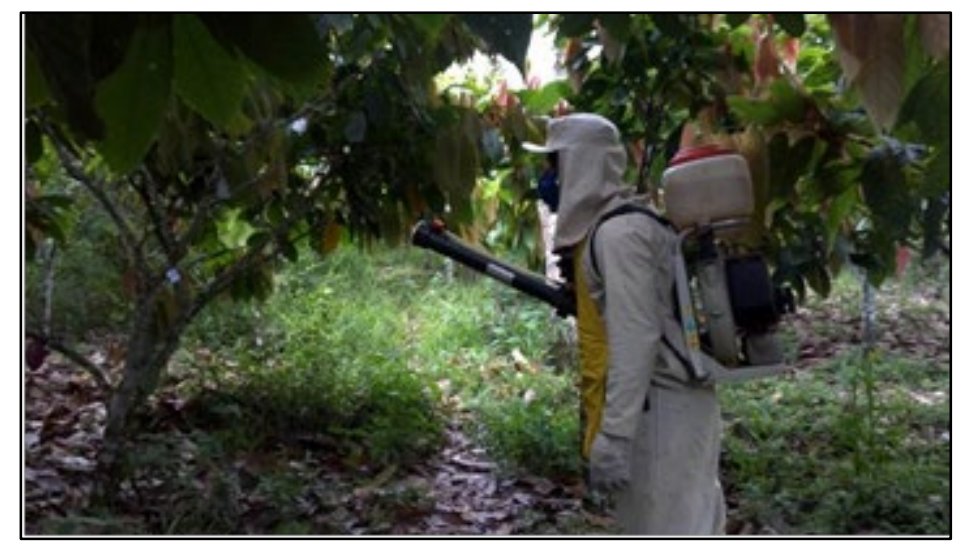

Source: Authors

\section{RESULTS AND DISCUSSION}

At the end of the experiment, the cow urine caused a reduction in the attack of both insects and witches' broom fungi in the cacao shoots, especially when applied at concentrations above 1\%, as shown in Figure 3.

Figure 3 - Percentage of cacao leaves attacked by insects and identification of the fungi after the plants were submitted to five treatments, where: T1 - Cow Urine at 0.5\%; T2 Cow Urine at 1.0\%; T3 - Cow Urine at 1.5\%, T4 - Decis ${ }^{\circledR}$ CE insecticide, and T5 - Control

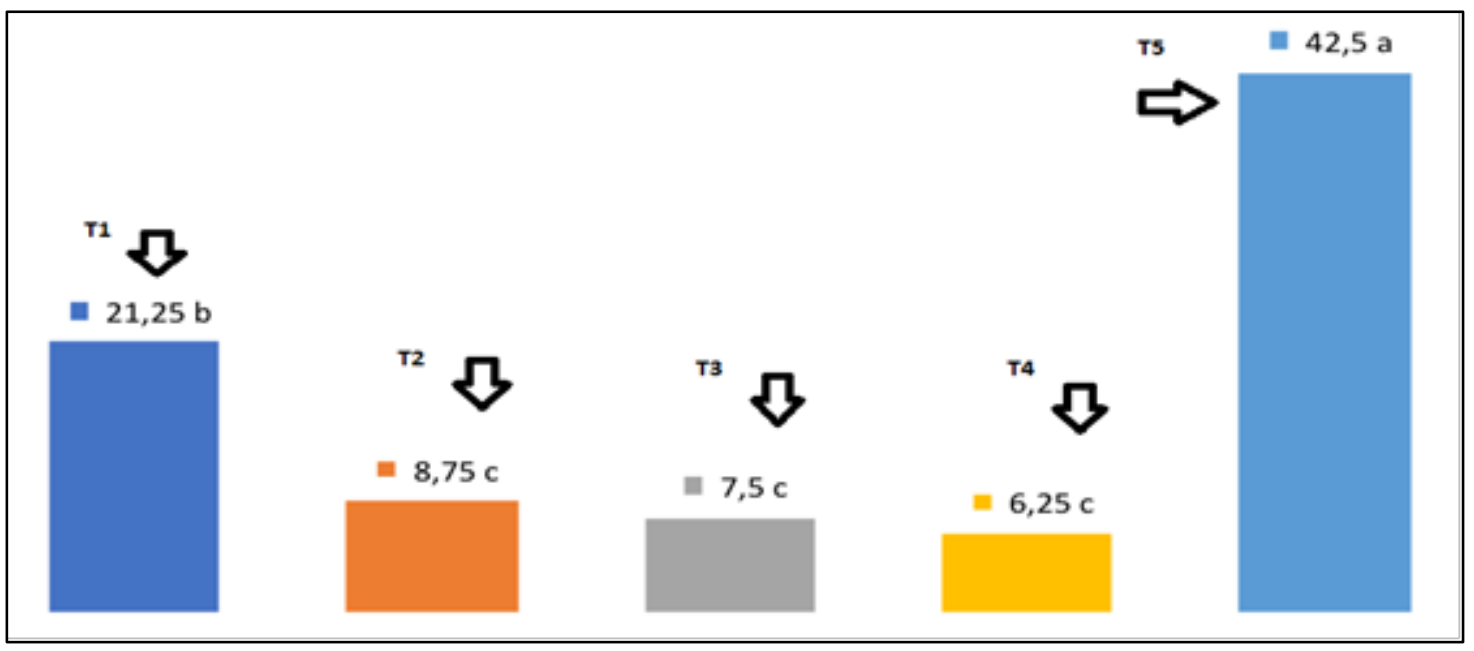

Note: Means followed by the same letter do not differ statistically between each other at $5 \%$ probability by the Tukey Test $(\mathrm{CV}=15.97 \%)$ 
According to the results shown in Figure 3, among the evaluated plants, the treatment that retained the highest incidence of leaves attacked by insects and fungus was the Control Treatment (T5), with $42.5 \%$ of affected leaves, indicating the real need for the cocoa crop to receive agents that control pests and, mainly, witches' broom.

Alves (2002) stated that the lack of efficient control measures has resulted, in recent years, in reduced production, changes in land use, the sale of properties, decreases in the level of employment, and damage to the environment.

It is noteworthy that cow urine is commonly found on family farmers' properties, thus reducing production costs. Its correct use reduces the need for pesticides and chemical fertilizers, in addition to not causing risks to the health of the producer and the consumer, nor damage to the environment since it is a product of organic synthesis, as long as the recommended doses are respected.

For the treatments using lactating cow urine, we found that Treatment T1 ( $0.5 \%$ cow urine), whose mean percentages obtained differ statistically by the Tukey test, at $5 \%$ probability, showed a reduction of $50 \%$ in relation to 15 , although $21.25 \%$ of the new leaves were attacked and contaminated.

Regarding the treatments that presented a smaller number of leaves affected by insects and diseases, we have: T4, with the application of $250 \mathrm{~mL}^{-h a^{-1}}$ of insecticide (6.25\%), T3, application of $1.5 \%$ of cow urine (7.5\%), and T2, application of $1.0 \%$ of cow urine $(8.75 \%)$. However, the mean percentages for the three treatments did not differ statistically by the Tukey test at 5\% probability.

According to Van Den Broek et al. (2002), cow urine has been widely studied for several applications in commercial crops. When mixed with water in different proportions, it can be immediately sprayed or stored in closed containers (usually non-transparent plastics). Dosages vary according to the intensity of the biotic agent targeted for control, and, according to the authors, the $30 \%$ dose was the most efficient to control powdery mildew (Erysiphe cichoracearum) in okra crops (Hibiscus esculetum). 
Silva et al. (2011), while studying the agroecological control of white mites (Polyphagotarsonemus latus, Banks) in physic nut (Jatropha curcas L) using different doses of cow urine and maniocjuice ${ }^{1}$ found that the control of these insects inphysic nut cultures was more efficient when the cow urine was used at concentrations of 250 and 1,000 mL/plant/application.

Similar results were reported by Gonzaga et al. (2009) when evaluating the toxicity of cow urine and cassava juice on insects in pineapple cultivation. The extracts were sprayed onto pineapple plants at two concentrations each ( 0.5 and $1.0 \mathrm{~L}$ in $20 \mathrm{~L}$ of $\mathrm{H}_{2} \mathrm{O}$ ). The analyzed levels caused insect mortality higher than $50 \%$, and the highest concentration of both extracts caused $100 \%$ mortality.

The effect of cow urine on plants is conferred by its composition, where several nutrients are found, such as N, P, K, Ca, Mg, S, Fe, Mn, B, Cu, Zn, $\mathrm{Na}, \mathrm{Cl}, \mathrm{Co}$, and Mo, attributing a fertilizing effect, in addition to phenols (substances that increase resistance) and indoleacetic acid, a natural plant growth hormone (BOEMEKE, 2002).

The element chlorine, present in cow urine in the order of 10,600 ppm (GADELHA et al., 2003; MENDES et al., 2004; SPINOSA et al., 2006), has good fungicidal, algaecide, protozoocidal, and viricide activity, as well as against vegetative forms of bacteria. The elementary chlorine available in the solution reacts with water and releases hypochlorous acid $(\mathrm{HClO})$ in its non-dissociated form, which has the ability to penetrate the bacterial cell and release oxygen, oxidizing several essential components of the bacterial protoplasm, causing the death of the cell (SPINOSA et al., 2006).

Meanwhile, the element copper may present some fertilizing effects, acting as a micronutrient. However, it can also act as a protective fungicide based on cuprous oxide, specifically, where it has been the most effective in controlling the

\footnotetext{
${ }^{1}$ Liquid extracted from cassava (Manihot esculenta Crantz) when pressed during the flour manufacturing process, called manipueira in native language.
} 
disease in fruits, but with little or no action on the leaves or floral cushions of the cacao tree (MAPA, 2017).

It is also worth mentioning that the chemical species present in lactating cow urine have a strong dependence on their diet due to the $\mathrm{pH}$ variation of the medium, which influences the ionic speciation of the elements present. According to Garcia-Navarro (1996), the pH of bovine species generally ranges between 7.4 and 8.4. In his study, when adding crude glycerin to the animals' diet, the $\mathrm{pH}$ of the urine varied from 8 to 9 , and without its addition, from 6 to 9 .

According to Sink (2006), the diet is a determining factor for urinary $\mathrm{pH}$, and changes in this parameter are considered physiological during the lactation period.

For Innecco et al. (2008), alternative pest control agents comprise chemical, biological, organic, or natural products with low to no aggression to man and nature, which act efficiently to combat harmful insects and microorganisms, in addition to not favoring the occurrence of pest and microorganism resistance, with high availability and low cost of acquisition and use, as well as simplicity in handling and application.

According to Altiere (2001), this technological package based on agrochemicals fosters many other consequences, such as increasing the vulnerability of agricultural production to unforeseen natural and human events. On the other hand, cow urine is already being used by family farmers in cacao plantations in southern Bahia, with satisfactory results in controlling insects and diseases in subsistence crops. Producers report that, in the applied areas, leaf shoots present better development and reduced attack of insects and diseases, without causing significant impacts.

Technological packages degrade their own productive base through the evolution of resistance to insecticides; loss of genetic diversity for plant breeding; loss of soil fertility through erosion, salinization, compaction, and loss of micronutrients; inadequate water use, and the creation of new pest-related problems (ALTIERE et al., 2003). 
The recovery of Bahian cacao crops requires practices that are sustainable from a socioeconomic and environmental point of view, given that some pesticidebased practices, such as the use of copper, insecticides, fungicides, and herbicides, do not bring the benefits that farmers expect in the long run, rendering the use of these products a dependency that only causes harm to everyone without distinction.

\section{CONCLUSION}

The use of lactating cow urine at doses of 1.0\% (2.4 L.ha $\left.{ }^{-1}\right)$ and, mainly, 1.5\% (3.6 L.ha ${ }^{-1}$ ), proved to be efficient in controlling insects and witches' broom disease in the cacao crop, without statistical differences when compared with conventional chemical treatment.

Further research is required to elucidate the efficiency of other dosages (such as $2.0 \%$ of lactating and non-lactating cow urine; application of more than a single dose, and the observed behavior; studies on the efficacy of other animal urines, for example), as well as the residual effect and the half-life of the cow urine in the vegetables, to be recommended to rural farmers.

\section{REFERENCES}

ACHLIYA, G.S.; MEGHRE, V.S.; WADODKAR, S.G.; DORLE, A.K. Antimicrobial activity of different fractions of cow urine. Indian Journal of Natural Products, 20:14-18. 2004.

ALVES, S.A.M. Epidemiologia da vassoura-de-bruxa [Crinipellis perniciosa (Stahel)] em cacaueiros enxertados em Uruçuca, Ba. Masters Dissertation. 70 p. USP, Piracicaba, December, 2002.

ALTIERI, M.A.; SILVA, E.N.; NICHOLLS, C.I. O Papel da Biodiversidade no Manejo de Pragas. Holos, Ribeirão Preto - SP, 226p. 2003.

ALTIERI, M.A. Agroecologia: a dinâmica produtiva da agricultura sustentável. 3. ed. Porto Alegre: UFRGS, 110 p. (Síntese Universitária, 54), 2001.

ANDRADE, M.P. Ilhéus: passado e presente. 2. ed. Ilhéus: Editus, 2003. 
BACKER, R.E.D.; CROWDY, S.H. Studies in the witche's broom disease of cocoa caused by Marasmius perniciosus Stahel: Introduction, symptoms and etiology. Port-of-Spain: ICTA, 28 p. 1943.

BERGAMIN FILHO, A.; HAU, B.; AMORIM, L.; LARANJEIRA, F.F. Análise espacial de epidemias. Revisão Anual de Patologia de Plantas, v. 10, p. 155-218, 2002.

BOEMEKE, L.R. A urina de vaca como fertilizante, fortificante e repelente de insetos. Agroecologia e Desenvolvimento Rural Sustentável. Porto Alegre, v.3, n.4, Oct/Dec, 2002.

CEPLAC - COMISSÃO EXECUTIVA DO PLANO DA LAVOURA CACAUEIRA - Características Gerais do Cacau. Available from: http://www.ceplac.gov.br/radar/cacau.htm. Accessed on: Feb. 03, 2019.

CLIMATE. Clima de Piraí do Norte. 2019. Available from: https://pt.climate-data.org/americado-sul/brasil/bahia/pirai-do-norte-312749/. Accessed on: Mar. 30, 2019.

EMBRAPA SOLOS. Sistema brasileiro de classificação de solos. Available from: http://www.infoteca.cnptia.embrapa.br/infoteca/handle/doc/1094003. Accessed on: Mar. 30, 2019. Rio de Janeiro, 2018. 412 p.

EVANS, J.; POORTER, $\mathrm{H}$. Photosynthetic acclimation of plants to growth irradiance: the relative importance of specific leaf area and nitrogen partitioning in maximizing carbon gain. Plant, Cell \& Environment, v. 24, n. 8, p. 755-767. 2001.

FREITAS, N.B. Floricultura Tropical no Sul Da Bahia, Semana do Fazendeiro, 27., Uruçuca, Agenda. CEPLAC/CENEX/EMARC, 2005.

GADELHA, R.S.S.; CELESTINO, R.C.A.; SHIMOYA, A. Efeito da utilização de urina de vaca na produção da alface. Pesquisa Agropecuária \& Desenvolvimento Sustentável, v. 1, n. 2, p. 179-182, 2003.

GARCIA-NAVARRO, C. E. K. Manual de Urinálise Veterinária. São Paulo: Livraria Varela, p.96, 1996.

GONZAGA, A.D; SOUSA, S.G.A; SILVA, N.M; PEREIRA, J.O. Toxicidade de Urina de Vaca e da Manipueira de Mandioca Sobre Pragas Chaves do Abacaxi. Resumos do VI CBA e II CLAA. Rev. Bras. de Agroecologia. Nov. Vol. 4 No. 2, pág. 1565 - 1567, 2009.

IBGE - Instituto Brasileiro de Geografia e Estatística. Pirai do Norte. 2019. Available from: https://cidades.ibge.gov.br/brasil/ba/pirai-do-norte/panorama. Accessed on: Mar. 30, 2019.

INNECCO, R; CARDOSO, S.S; SANTOS, L.R.R. Métodos alternativos de controle de pragas e doenças. Belém - UFPA, p43, 2008. 
LUZ, E.D.M.N.; BEZERRA, J.L; RESENDE, M.L.V.; OLIVEIRA, M.L. Doenças do cacaueiro. In: VALE, F.X.R.; ZAMBOLIM, L. (Eds.) Controle de doenças de plantas. Viçosa: UFV/Imprensa Universitária, pp. 611-616, 1997.

MAPA - Ministério da Agricultura, Pecuária e Abastecimento, Cultivo do cacaueiro no Estado da Bahia, 1. Ed. CEPC, p126, 2017.

MAMÉDIO, J.E.S. Análise do uso de agrotóxicos na lavoura cacaueira em propriedades de agricultores familiares no município de Piraí do Norte - BA. Paper apresentado ao curso de Especialização em Agroecologia, IFPR, 2012.

MENDES, A.A.; NAAS, I.A.; MACARI, M. Produção de Frangos de Corte. Campinas, FACTA, Fundação APINCO de Ciência e Tecnologia Agrícola, Cap. 8, p.117- 119. Cap. 11, p.171-173, 2004.

OLIVEIRA, A.P.; PAES, R.A.; SOUZA, A.P.; DORNELAS, C.S.M. Rendimento de pimentão adubado com urina de vaca e NPK. In: 43 Congresso Brasileiro de Olericultura, Recife. Resumos, SOB. CD-ROM. 2003.

PARANÁ. Secretaria da Agricultura e do Planejamento. Agrotóxicos - Inseticidas. 2013. Available from: http://www.agricultura.pr.gov.br/arquivos/File/defis/DFI/Bulas/Inseticidas/DECIS_25_EC.pdf. Accessed on: Jun. 10, 2019.

PESAGRO - RIO. Utilização de urina de vaca. Available from: http://www.pesagro.rj.gov.br/urinavaca.html. Accessed on: Mar. 02, 2019.

PESAGRO - RIO. Urina de vaca: alternativa eficiente e barata. Rio de Janeiro, Documentos, n. 96. 8p. 2002.

PINAZZA, L.A.; ALIMANDRO, R. Uma longa crise. (In) Revista de Agronegócios da FGV. Agroanalysis; Rio de Janeiro, p. 59, September, 2001.

SANTOS FILHO, L.P.S.; FREIRE, E.S; CARZOLA, I.M. Estimativas de Perdas de Produção de Cacau Causadas por Vassoura-de-Bruxa (Crinipellis Perniciosa (Stahel) Singer) na Bahia. Agrotrópica, v. 10, n. 3, Ilhéus, BA, Brasil, CEPLAC/CEPEC, 1998.

SILVA, K.E.; NÁPOLES, F.A.M.; SOUZA, G.A.V.S.; MONTENEGRO, F.T.; FERREIRA, T.C.; SOUZA, J.T.A. Controle agroecológico do ácaro branco (Polyphagotarsonemus latus, Banks) no pinhão manso (Jatropha curcas L) com diferentes dosagens de urina de vaca e manipueira. Resumos do VII Congresso Brasileiro de Agroecologia - Fortaleza/CE. Cadernos de Agroecologia, Vol. 6, No. 2, December, 2011.

SINK, C. A. Urinálise e hematologia: laboratorial para o clínico de pequenos animais. São Paulo: Roca, p128, 2006. 
SOARES, E.S. Impactos causados à saúde do trabalhador rural que manipula agrotóxicos na Região Cacaueira do sul da Bahia. Masters in Territorial Planning and Social Development - Universidade Católica do Salvador, 2011.

SPINOSA, H., GORNIAK, S., BERNARDI, M. Farmacologia Aplicada à Medicina Veterinária. 4. ed. Rio de Janeiro: Guanabara Koogan, Cap.35, p. 441-447, 2006.

VAN DEN BROEK, R. Controle alternativo de oídio (Erysiphe cichoracearum) em quiabeiro (Hibiscus esculetum). Revista Ecossistema, v.27, n.1,2, Jan.-Dec., 2002.

\section{Authorship contributions}

\section{1 - José Eduardo Santos Mamédio}

Engenheiro Agrônomo

http://orcid.org/0000-0002-7764-9057-eduardo_mamedio@yahoo.com.br

Contribuição: Autor principal da concepção da idéia, do experimento, da implantação e condução do mesmo em campo.

\section{2 - Uberson Boaretto Rossa}

Doutorado em Engenharia Florestal

http://orcid.org/0000-0003-1222-2236-uberson.rossa@ifc.edu.br

Contribuição: Na qualidade de Engenheiro Florestal analisou as correlações e efeitos dos tratamentos nos cacaueiros.

\section{3 -Frederico Fonseca da Silva}

Doutorado em Irrigação e Meio Ambiente http://orcid.org/0000-0003-2817-6983-frederico.silva@ifpr.edu.br Contribuição: Orientador principal e responsável pelos dados coletados, análises e revisão das etapas do trabalho.

\section{4 -Wilson Sacchi Peternella}

Doutorado em Química do solo

http://orcid.org/0000-0003-3931-515X-wpeternella@yahoo.com

Contribuição: Na qualidade de Bacharel em química avaliou os componetes químicos dos tratamentos e as suas correlações entre planta e doença.

\section{5 -Vanderlei Bett}

Doutorado em Zootecnia http://orcid.org/0000-0002-1019-5134-vand.bett@idr.pr.gov.br Contribuição: Na qualidade de Médico Veterinário e Zootecnista avaliou as relações da urina das vacas em lactação. 


\section{How to quote this article}

MAMÉDIO, J. E. S.; ROSSA, U. B.; SILVA, F. F.; PETERNELLA, W. S.; BETT, V. Efects of cow urine in the agroecological management of insects and witches' broom (Moniliophtora perniciosa Stahel Aime \&Phillips-Mora) in cacao crops (Theobroma cacao L.). Ciência e Natura, Santa Maria, v. 43, e4, p. 1-16, 2021. Available from: https://doi.org/10.5902/2179460X46917. Accessed: Month Abbreviated. day, year. 